\title{
Friction Between Kejawen Islam and Puritan Islam in Religious Tourism in The Area of "Masjid Gedhe Mataram" Kotagede, Yogyakarta
}

\author{
MONA ERYTHREA NUR ISLAMI \\ Dept.of Tourism \\ AMPTA Tourism Institute \\ Yogyakarta, Indonesia \\ mona234sc@gmail.com
}

\author{
NUHARANI ERNINGDYAH K. \\ Dept.of Tourism \\ AMPTA Tourism Institute \\ Yogyakarta, Indonesia \\ nuh4r4n1@yahoo.co.id
}

\author{
DIAH ENGGARWATI \\ Dept.of Tourism \\ AMPTA Tourism Institute \\ Yogyakarta, Indonesia \\ diah.enggar@yahoo.com
}

\begin{abstract}
Pilgrimage practices in Indonesia are increasing, especially the last three decades since the government launched the "religious tourism" program. This phenomenon is also seen in the area of Masjid Gedhe Mataram Kotagede, Yogyakarta. This research aims to describe the friction between Kejawen Islam and Puritan Islam in the area of Masjid Gedhe Mataram Kotagede Yogyakarta. This is a case study research with data collection techniques in the form of observation and interviews. Observations focused on the visitor behavior of Masjid Gedhe Mataram Kotagede, the behavior of pilgrims at the Kotagede Mataram Kings Cemetery, and the atmosphere around the complex of Masjid Gedhe Mataram Kotagede. While the interview was conducted to find out the friction that occurred in the complex of Masjid Gede Mataram Kotagede Yogyakarta.
\end{abstract}

The results indicate two things, namely: (1) The friction between Kejawen Islam and Puritan Islam in the area of Masjid Gedhe Mataram Kotagede occurs because of differences in interests and differences in views between the manager of Masjid Gedhe Mataram Kotagede and the manager of tombs' kings; (2) Activities carried out by visitors at Masjid Gedhe Mataram Kotagede are sholat, dhikr, itikaf, and attending science assemblies, while activities carried out by pilgrims at the Tombs of Kotagede Mataram Kings are reading tahlil, burning incense, doing meditation.

Keywords-religious tourism, kejawen Islam, Puritan Islam, Masjid Gedhe Mataram, Kotagede Mataram Kings Cemetery.

\section{INTRODUCTION}

Religious tourism with the motivation to fulfill spiritual needs occupies an important segment of international tourism and has grown substantially in recent years. Consistent growth in this market segment has become a global trend in tourism. (Jaelani, 2017: 1). Even though the journey with religious motives has been going on for centuries. Because every year many people travel with the purpose of the site mentioned by the scriptures, such as the Qur'an and the Bible.

Yogyakarta, in addition to being a cultural tourism destination is also a religious tourism destination and pilgrimage. Some of the places that become religious tourism destinations and pilgrimages are the graves of Kyai, such as the grave of Kyai Nur Iman in Mlangi, the tomb of Syeh Maulana Maghribi at Parangtritis Beach, and the tomb of Kyai Munawir on Dongkelan. Not only the tombs of the Kyai, the tombs of kings also become pilgrimage attractions, such as the tomb of Hastorenggo and the tomb of Panembahan Senopati in Kotagede, the tomb of kings in Imogiri.

When viewed from the pattern of tourist visits, there are different sets of pilgrimage activities. For the nadhiyin, a series of pilgrimage activities usually choose the graves of the kyai, such as the tomb of Wali Songo, the tomb of the kyai who was a santri teacher at the Islamic boarding school. For kejawen, a series of pilgrimage activities usually is a visit to the tombs of kings, such as the tomb of the founding kings of the Mataram kingdom in Kotagede and the king's petilasan at Parangkusumo Beach.

The tomb of Mataram kings and Masjid Gedhe Mataram located in Kotagede, are two religious tourism objects that have been visited by tourists with various destinations. If observed further, there are also differences in visitor segments between the two objects. Apart from that there was a separate management between the tombs of Kotagede Mataram kings and Masjid Gedhe Mataram Kotagede. In fact, when viewed from its history, between Masjid Gede Mataram Kotagede with the tombs of kings in Kotagede is a historical series. The existence of Masjid Gedhe Mataram Kotagede cannot be separated from Panembahan Senopati as one of the ulama who preached to spread Islam in Java at that time. Before changing its function to a tomb, the place was once the residence of Panembahan Senopati and his family.

Masjid Gedhe Mataram Kotagede which was founded by Panembahan Senopati, after his death, the mosque was managed by the servants of the mosque of the Yogyakarta Sultanate Palace. In 1990, at the request of Gusti Joyokusumo, one of the relatives of the Yogyakarta Sultanate palace, the management of the mosque was handed over to the surrounding community with the aim that Masjid Gedhe Mataram Kotagede would be more prosperous. The transition of the management of the mosque seems to be a sign of the shift of kejawen domination to a more moderate Islam. The phenomenon that occurred at the tombs of the Kotagede kings and Masjid Gedhe Mataram was the concern of the writer to conduct a study to answer the research questions that emerged, namely:

1. What factors led to the friction between the manager of the tombs of the Mataram kings in Kotagede and the manager of Masjid Gedhe Mataram in Kotagede? 
2. What is the behavior of visitors of the tombs' kings of Mataram in Kotagede and visitors of Masjid Gedhe Mataram in Kotagede?

\section{RESEARCH METHODS}

The method used in this study is a qualitative research method. Bog and Taylor (in Moleong, 2000: 3) define qualitative methodology as a research procedure that produces descriptive data in the form of written or verbal words from people and observable behavior. This approach is directed at the background and individual holistically (intact). The qualitative study of the phenomenon of Islam in Kotagede aims to understand the process of friction between the values brought by the Kejawen Islamic group and puritanical Islam. Friction will be known through reasons, explanations, in the form of attitudes, views and actions of the two opposing groups. In order to get a broader and deeper understanding of the social situation under study, the method used to retrieve data is by observation and interview. Marshall (in Sugiyono, 2011: 226) states that through observation, researchers learn about the behavior and meaning of the behavior. While the interview according to Susan Stainback (in Sugiyono, 2011: 232) is the way researchers know things more deeply about participants in interpreting situations and phenomena that occur, where it cannot be found through observation. The informants in this study were servants of the tomb of kings in Kotagede, visitors to the tombs of kings in Kotagede, administrators (takmir) of Masjid Gedhe Mataram Kotagede. The object of the research is the grave of Kotagede kings and Masjid Gedhe Mataram Kotagede.

\section{ANALYTICAL RESUlTS}

From the results of interviews and observations to the managers of the tombs of the kings in Kotagede and the manager of Masjid Gedhe Mataram Kotagede, there was a friction between the two managers. The occurrence of friction is caused by differences in interests based on economic interests and differences in views on pilgrimage.

\section{A. Differences in Interest Between Grave Managers and Mosque Managers}

The friction that occurs based on economic interests is triggered by the jealousy between the managers of the tomb of the kings towards the mosque management because it is considered that the income and voluntary funds from the visitors to the mosque are greater than the income obtained from the tomb. For the grave manager, the income earned by the mosque is only used for the personal benefit of the mosque manager, as revealed by one of the tomb servants, Mr. Daryanto. This jealousy was also triggered by the transfer of the management of the mosque from the mosque servants to the takmir mosque which was formed by the surrounding community and received approval from the Yogyakarta Sultanate. This management transition resulted in a reduction in the authority of courtiers to the management of the mosque including the management of funds.

In contrast to the opinions expressed by one of the tomb servant, Mr. Daryanto, one of the mosque administrators,
Mr. Warisman explained about managing the income for the mosque. He explained that the income coming from the visitors coming to the mosque was used entirely to prosper the mosque. The activities of prospering the mosque include religious activities such as recitation, distribution of free groceries for worshipers who diligently pray together in mosques, health programs by opening a health clinic for anyone. Responsibility for the use of funds by the mosque is evidenced by the existence of routine and open financial reports for anyone to see, This is what distinguishes financial management carried out by the servants of the cemetery, where there are no open reports of the results of the management of funds obtained from grave infaq and clothing rental.

\section{B. Differences in Views between Grave Managers and Mosque Managers}

1) The view of GraveManagers in Kotagede about pilgrimage.

There are several differences in views between the grave manager and the mosque manager regarding the pilgrimage and the rules for entering the grave. In the opinion of $\mathrm{Mr}$. Daryanto, one of the servants in the grave management, the pilgrimage does not mean asking for help to the deceased. Pilgrimage is a ritual of sending invocations to people who have died then praying directly to Allah. Because "we adore people who are lay down here in this tomb, then Allah willing to grant requests. However, Mr. Daryanto does not deny that there are also abdidalem who offer themselves as intermediaries to ask for help to people who have died in an effort to make their wishes come true. According to him, this is considered a trick to attract the sympathy of visitors.

Unlike the opinion of Mr. Daryanto, one of the visitors who came from Cepu, Mr. Salimun revealed the purpose of him and his entourage called "Penget Family" to visit the tomb because they wanted to "bless blessings". The series of pilgrimage activities carried out by Mr. Salimun always began with a pilgrimage to the summit of Mount Lawu then to the tomb of the kings in Kotagede and finally to the PanembahanSenopati retreat on ParangKusumo Beach. The series of regular pilgrimage activities were carried out by Salimun in the month of Sura (Muharram) because for the Javanese, the month of Sura was a good month to send invocations. The basis for the pilgrimage is suggestion, and the belief that after returning from the pilgrimage, his mind is calm, and the perceived impact is the smoothness of sustenance.

According to the grave manager of the kings in Kotagede, the rules imposed when entering the tomb were the standard rules applied by the Yogyakarta Sultanate Palace. The rule was made since the time of HB I and is still valid today (see Fig. 1). The tomb entry regulation states that: (1) women wear jarik, kemben, and loose veil; (2) Men wearing peranakan, jarik cloth, and blangkon;(3) Equipment can be rented at the secretariat office;(4) It is prohibited to take pictures in the tomb. Why is the rule made in such a way, for courtiers this is not something that must be questioned but must be obeyed. Furthermore, Mr. Daryanto revealed that the rule was made because it aims to respect ancestors. 


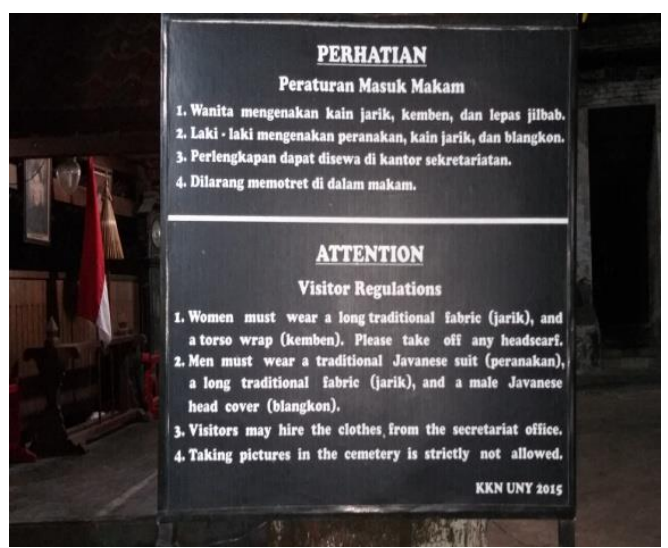

Fig. 1. Rules entering the tomb

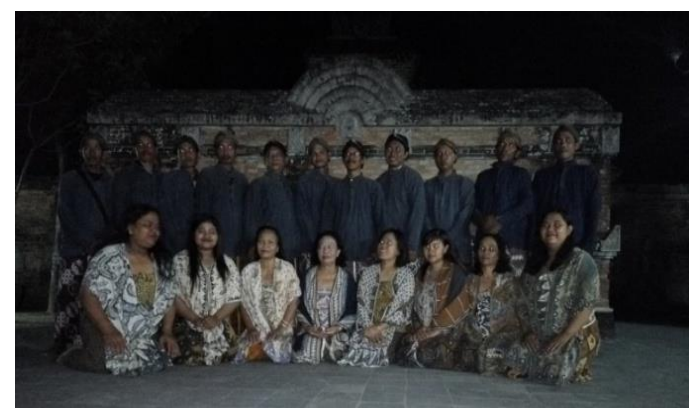

Fig. 2. Costum entering the tomb

2) The View of the Manager of Masjid Gedhe Mataram Kotagede AboutPilgrimage

Pilgrimage in the view of Islam is not prohibited, but it is recommended. Because the meaning of pilgrimage for Muslims is to remind the death. As revealed by one of the mosque takmir of Masjid Gedhe Mataram Kotagede, Mr. Warisman. He said:

"Those who traveled did the pilgrimage was no problem. Because the prophet used to forbid the pilgrimage but finnaly recommended it. In fact the pilgrimage also has benefits, first, that is the right purpose of praying for the dead. Then the second is to remind that every single will die. Well, those are the two benefits of pilgrimage. Yes, that was according to the guidance of the prophet. If it's done like that, ok, that's right.'

The thing that is forbidden in Islam, according to $\mathrm{Mr}$. Warisman is 'bertawasul' to people who have died. Bertawasul is asking someone who has karomah but has died to pray for us. Asking for help in people who have karomah is considered to be more facilitating blessings, because the person has a close relationship with God. But the condition that must be fulfilled is that the person is still alive. If you are dealing with a person who has died because the deceased person is a person who has 'supernatural power', then this is considered heretical. Because people who have died have lost their charity and they can't do anything. While the intention to 'bless blessings' should not be done in places like the tombs of kings in Kotagede, because Allah has promised that there are places that are blessed so that invocations can be granted, such as, in Masjidil Haram, Hijr Ismail, Multazam, Maqom Ibrahim, Rawdah. So, in a pilgrimage tour tourists should pray for, be able to know their history and then be able to imitate all the good behavior of people who have died, such as inheriting the spirit of PanembahanSenopati to preach to spread Islam at that time.

Regarding the rules for entering the tomb, especially those that apply to female visitors, it is clearly very contrary to Islam. According to Mr. Warisman, the female genitalia should be guarded, but the Yogyakarta Sultanate's court did not care about that. This is very unfortunate by Mr. Warisman who is one of the manager of Masjid Gedhe Mataram Kotagede.

\section{Visitor behavior}

The market segmentation of tourists visiting the tombs of kings in Kotagede is represented by the Kejawen Muslims or the nadliyin. The purpose of the visitors came to the tombs of the kings in Kotagede, as revealed by Mr. Daryanto (court servant of the Yogyakarta Sultanate's graveyard) is 'bless blessings' or 'golek pesugihan'. According to Mr. Daryanto, many state officials have visited the tombs of Mataram kings in Kotagede. They come when they have a will/desire, such as a presidential election. The behavior of visitors when they come to the tombs of kings in Kotagede starts from meditating or praying by burning incense or frankincense, or using oil, reading tahlil, bathing or just taking water in SendangSeliran to get blessings. There are even visitors who keep quiet doing rituals to get "supernatural powers". Visitors with behavioral characters like the above are almost certainly rare to visit the mosque of Gedhe Mataram which is located in one area with a tomb. This is a little different from visitors from the nadliyin who will also visit the mosque to pray after making a pilgrimage or before making a pilgrimage.

Despite differences in terms of beliefs and interests, Mr. Warisman said he would continue to help each other in muamalah affairs. This is corresponded to the results of Nakamura's (1983) study that the puritanism movement that developed in Kotagede was more tolerant. However, the internal Islamization process as called Nakamura does not occur in the area of the tombs of kings in Kotagede, because puritanical Islamic groups prefer to behave "lakum diinukum waliyadin".

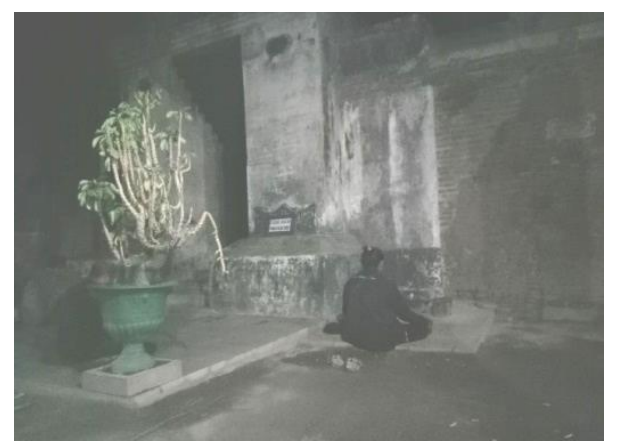

Fig. 3. Visitor Behavior of The Tombs of Mataram Kings in Kotagede 


\section{DISCUSSIONS}

Kejawen Islam is a mixture of Islamic doctrine and Javanese understanding. Niels Mulder (2001 : 39) views Kejawen as a way of looking at things, ways of looking at the world, which are indeed shown by certain external conditions. For Niels Mulder, kejawen was at the core of Javanese culture, and although kejawen was not a religion, it did contain religious attitudes, namely a view of life that did not distinguish between the sacred to the afterlife and the worldly. The essence of kejawaan is combining various elements that are derived from the original historical period of the development of Hindu Buddhism in this island, which is combined with more ancient animistic thoughts. As a system of knowledge, kejawen is very broad and complex, and contains cosmology, mythology, and mystical teachings, which produce a view of human existence, or the idea of human nature and the life of society, which then explains ethics and morality that permeate way and attitude of life.

Some of the characteristics of kejawen are:

a. Although kejawen adherents join religion among the religions served by the government, they still adhere to the original Javanese tradition;

b. Religion for kejawen adherents is manunggalingkawulaGusti, although this understanding is opposed by puritans

c. Kejawen are more dimensions of Sufism with a model developed mixed with other religious cultures;

d. King as leader, both government leader and religious leader;

e. The Mahabharata and Ramayana books are a source of inspiration for kejawen that contain the teachings of character morality and life-guiding behavior;

For some Muslim communities in Java, Islam has become part of their culture. Muslim religious behavior on Java is expressed a lot through entrenched traditions, in addition to the formal behavior of religion or worship. The followers of Kejawen Islam generally do not have formal religious organizations.

Whereas puritan Islam is an Islam that seeks to purify Islam from outside influences (including culture) both in the form of religious beliefs, thoughts and practices (Afida, 2015: 1). Purification movement (purification) is a phenomenon of the religious movement towards purity of belief that seeks to distance the syncretic tradition that contains (Superstition, Bid'ah, Khurafat), in Indonesian abbreviated by TBC. In the Geertz classification, the purification movement was supported by the santri in the Javanese religious typology besides abangan and priyayi. The consistency of the puritan Islamic religious movement requires the tajdid movement (renewal) covering:

1. purification, understanding, appreciation, and practice of religious originating in sacred doctrines;

2. The modernization and renewal of management and the movement of the public relations by remaining based on the originality of religious teachings (Sutiyono, 2010: 50-51)
Peacock, as cited by Sutiyono (2010: 51), presents the concept of puritan teaching based on the teachings of Islamic renewal driven by figures who have gained inspiration from the religion of renewal in the Middle East. The reformers prioritize the holy verses written in the Koran rather than the interpretation of the clever scholars (Kiai), facilitate the ceremony, and eradicate the worship of saints and their spirits, and worship which diverts one's attention from his worship to God. By following this characterization, the religious renewal movement wants to improve its religious system, simplify and restore the system at the time of authenticity before being destroyed. Truth must be sought alone, not from excessive interpretation of the religious authorities (ulama), but directly from the verses of the relevant scriptures. The result to be achieved is purification (puritanism) of religion as brought by Muhammad SAW. Puritan organizations such as Muhammadiyah, Persatuan Islam (PERSIS), JamahTabligh, Jamaah Salafi, Assembly of Al-Qur'an Interpretation (MajelisTafsir Al Qur'an).

Differences in interests and differences of views between the managers of the Masjid Gedhe Mataram Kotagede and the manager of the tombs of the kings of Kotagede resulted in the management of tourism in the place becoming separate. Whereas when viewed from the history of the existence of the Mataram Gedhe mosque and the tombs of the kings of Kotagede it is an inseparable series of stories. From the history, there can actually be developed a series of religious tourism activities, namely pilgrimage, but also visiting mosques as learning media. The development of religious tourism concepts that are not limited to pilgrimage activities but also to increase knowledge, add to the faith in Ibroh in the da'wah carried out by Panembahan Senopati who has a mission to spread Islam in Java at that time is difficult to realize because of the differences

\section{CONCLUSION}

Based on the results of the study it can be concluded that:

1. There is a difference of views between the manager of the tomb of the kings in Kotagede and the manager of Masjid Gedhe Mataram in Kotagede. The difference is based on differences in beliefs, in this case concerning pilgrimages and rules made by the Yogyakarta Sultanate palace when it entered the tomb which required wear Javanese dress customs that is using kemben and jarik for women and using jarik and surjan for men. The rules for not wearing the hijab when entering into the tomb are contrary to Islamic law.

2. Jealousy arises from the manager of the tomb of the kings in Kotagede against the manager of Masjid Gedhe Mataram in Kotagedewhich is based on economic interests. The grave manager saw that the transfer of the management of the mosque servants to the community had eliminated many of the courtiers' authority over mosque management including the management of the entry into the mosque. The grave manager saw that the transfer of management from the mosque servants to the community had eliminated many of the courtiers' authority over the management of the mosque 
including the management of income from those entering the mosque.

3. Different behaviors were shown by visitors who came to the tombs of the kings in Kotagede with the visitors coming to the mosque of Gedhe Mataram in Kotagede. As is the characteristic of the Kejawen Islamic group, the behavior shown by visitors to the tomb is meditating by burning incense or frankincense, doing tahlil, performing rituals for 'nggolek ilmu' (getting supernatural powers), bathing to 'bless blessings'. While the activities carried out by mosque's visitors are sholat, dhikr, reading the Koran or just discussing Islam.

\section{REFERENCES}

[1] Aan Jaelani. 2017. Industri Wisata Halal di Indonesia : Potensi dan Prospek (Halal Tourism Industry in Indonesia : Potential and Prospect). MPRA Paper, No. 76237, posted 17 January 2017 02:56 UTC. Halaman $1-20$.

[2] Achmad Rosidi. 2016. Eksistensi Yayasan Sadhar Mapan di Kota Surakarta dan Perkembangan Spiritualitas Hindu Jawa. Penamas (Jurnal Penelitian Keagamaan dan Kemasyarakatan), Volume 29, Nomor 2, Juli - September 2016, halaman 315 - 332
[3] Clifford Gertz. 1981. Abangan, Santri dan Priyayi dalam Masyarakat Jawa. Terjemahan Aswab Mahasin. Jakarta : Pustaka.

[4] Iklila Nur Afida. 2015. Konflik antara Majelis Tafsir Al-Qur'an (MTA) dan Nahdatul Ulama (NU) dalam Praktek Keagamaan di Kabupaten Bantul. Skripsi. Fakultas Syari'ah dan Hukum, Universitas Islam Negeri Sunan Kalijaga Yogyakarta.

[5] Lexy J. Moleong, Dr, M.A. 2000. Metodologi Penelitian Kualitatif. Bandung : PT Remaja Rosdakarya.

[6] Mitsuo Nakamura. 1983. Bulan Sabit Muncul Dari balik Pohon Beringin. Studi tentang Pergerakan Muhammadiyah di Kotagede, Yogyakarta. Yogyakarta : Gadjah Mada University Press. (Terjemahan dari The Crescent Arises over the Banyan Tree. Yogyakarta : Gadjah Mada University Press, 1983).

[7] Niels Mulder. 2001. Ruang Batin Masyarakat Indonesia. Yogyakarta : LKIS

[8] Sutiyono. 2010. Benturan Budaya Islam : Puritan dan Sinkretis. Jakarta : PT Kompas Media Nusantara.

[9] Sugiyono. 2011. Metode Penelitian Kuantitatif Kualitatif dan R\&D. Bandung : Penerbit Alfabeta.

[10] Fieldnote Wawancara dengan Bapak Daryanto, abdi dalem Keraton Kasultanan Yogyakarta, tanggal 29 September 2018

[11] Fieldnote Wawancara dengan Bapak Salimun, pengunjung makam raja-raja Kotagede, tanggal 29 September 2018.

[12] Fieldnote Wawancara dengan Bapak Warisman, takmir Masjid Gedhe Mataram Kotagede, tanggal 30 September 2018. 